\title{
Service Quality and Performance of Public Sector: Study on Immigration Office in Indonesia
}

\author{
Ernani Hadiyati ${ }^{1}$ \\ ${ }^{1}$ Schoolof Economics and Business Faculty, Gajayana University, Malang, Indonesia \\ Correspondence: Ernani Hadiyati, Schoolof Economics and Business Faculty, Gajayana University, Malang, \\ Indonesia.Tel: 62-812-358-4748.E-mail: ernani_hadiyati@yahoo.com
}

Received: October 8, 2014

Accepted: November 1, 2014 Online Published: November 24, 2014

doi:10.5539/ijms.v6n6p104

URL: http://dx.doi.org/10.5539/ijms.v6n6p104

\begin{abstract}
The objectives of the research are to describe the public sector service form delivered to consumers/citizen, to find out the consumers' satisfaction on public sector service, and to discover the public sector quality and performance delivered to consumer/people. The research is to measure the level of consumers' satisfaction in using the public sector services through government policy approach towards the service satisfaction, and people's judgment towards the quality and performance served by public service administrator apparatus. This research results in, first, description of the public sector service form delivered to consumers/people as the public sector service users, second, measuring the consumers or people's satisfaction based on the public sector service satisfaction measurement indicator in reference to government's decrees and laws, and third, determining the public sector service performance and quality applied to the consumers/people. The result of the research is of benefit for the government's consideration as public sector service administrator for consumers/people in the effort to ameliorate the service performance and quality.
\end{abstract}

Keywords:customer satisfaction, quality service, performance, public sector, immigration office

\section{Background}

The field of public service indicates a shift towards market orientation principle implementation in providing services (Osborn \& Gaebler, 1999), which means that the services applied by the government prioritise the consumers/people. The statement is supported by the catalytic government principle where the government apparatus functions as a catalyst in giving public service, and guarantees its ease.

Zamil (2011) explains that the government, as large organizations, has customers and the customers are the citizens, businesses sector, public and private employees. Government through agencies, departments, and ministries provides information and services for each customer group and as a result, the customers give their assessment to the performance delivered.

In accordance to people's needs service demands keep changing as the globalisation grows. People's demands are strongly dependent on the level of needs and the individual and social value. This, therefore, enforce the apparatus to role more positively in assisting people to fulfil their needs.

Nor et al. (2010) states that public sector organizations, which provide customer service is one of the important factors that gives significant contribution to build good reputation and credibility in the community. Public complaints of long queues, poor service and poor physical facilities are not adequate to affect the image and the quality level of service in the public sector.

According to Teicher et al. (2002), the practice of service quality in public sector organizations is slow and furthermore it is exacerbated by the difficulty in measuring the outcomes, considerablesurveillance of the press and the public, the lack of freedom to improvise freely and the need for decisions to be based on the law.

In reference to policy legislation number 32 year 2004 on regional administration, in accordance to public service, shorter point of delivery to the public is expected. Thus, consequently, there must be an authority delegation to the lower level of administration - regency.

Ilhaamie (2010) suggests that service quality performance on governmental organisation service quality is of the major dimension in public sector as the output of an organisation is public services. Besides, profit is not the goal 
of public organisations since they are playing such different roles as becoming facilitators, giving fast response, and developing socio-economy (Arawati, Baker,\&Kandampully, 2007).

A dynamic improvement on social condition, such as welfare melioration, is an indication of people empowering in society (Thoha, 2004). It can be implied that people are more aware their rights and obligations as citizens of a nation. People are more outspoken towards their demands and aspiration to the government. People are more critical and straightforward to control whatever step taken by their government.Zamil, Shammot (2011) asserts that traditionally, the government did not consider the citizens as their customers but as the people who pay for the provided services, therefore it will run properly and smoothly. Society is the customer and they must be satisfied. Public employees should understand that they get their salary from serving people effectively.

Hsiao, Chih - Tung and Jie - Shin Lin (2008), from their results of the study, states that the public sector organizations conducted the identification, not only external factors of the customers, but also includes internal employees. It is very important to incorporate customer needs into the procedures design of service. Information of customer complaint will be used by public sector organizations as a strategic development in public sector of service delivery system.

Government is required to be more aware about its social function in gratification of people's needs and welfare enhancement, if not all, to be strategically, though indirectly, be responsible for the people's development and advancement. The public service implemented by the government is frequently a reflection of general bureaucracy quality. Consequently government needs to make improvement on public service quality to gain people's satisfaction. The government policy in relation to public service can be referred from Decree of Apparatus Empowerment Ministry number: KEP/25/M.PAN/2/2004 about General Guidelines for Public Satisfaction Index Preparation in Government Instances Services Unit. In an effort to advance the quality of public services, the government has enacted laws Number: 25 Year 2009 about the Guideline of Public Service Quality Improvement with Community Participation. The law states that the best service is the rights of every person in using public service. It is supported by Cohen \& Brad (1993) suggesting that to guarantee the national welfare, the public sector service performance must be decreed. Service improvement makes more productive public sector organisation.

Mori (2004) argues that, when the government provides services to clients, which are represented by the departments, ministries, agencies, and other public sector organizations should classify customers into significant segments before the customer defined their material needs and expectations in a number of segments, such as housing, benefits, social care, environment, library, and recreation, education, and public safety (Improvement and Development Agency for Local Government, 2005).

One of the forms of the public service is the bureaucracy of applying a passport in Immigration Office. Globalisation has impacted on the escalation of international travel of various purposes such as trade, business, tourism, and so forth. Each country has its sovereignty to set regulation of whoever or whatever coming to or leaving, whether to visit or stay for specific period of time. So this is sensible that there isan escalation number of passport applicants in Immigration Office Class 1, Malang. Based on the interview with one of the officers, there is a constant increase of passport applicants who especially plan for Umroh (Islamic pilgrimage) and tourism purpose. A related study on public opinions about using public sector service by Setyaningsih (2008) states that administrative service quality in Sragen District Police Department is in overall good, albeit there are still 2 out of 14 elements — service justice and safety—stillregarded as poor.

\section{Review of Related Literature}

\subsection{Service Quality}

According to Ministry Decree of PAN No. 25/M.PAN/2/2004, public satisfaction is measured from the people's opinions and judgments towards the service performance of public service administrator apparatus.

Quality as a strategic tool to achieve operational efficiency and improve organizational performance(Anderson, 1995; Babakus \& Boller, 1992; Garvin, 1983: Philips et al., 1983). According to Garvin (1987), the conceptualized quality has eight dimensions including: performance, features, reliability, conformity, durability, service, aesthetics, and perception.Dimensions of service quality such as personal knowledge and potential, humility, completeness of service, speed of delivery, aesthetics are also important important aspects to achieve quality (KatsoTushiAyano, 2005)

Lovelock and Wirtz (2004) adds another dimension of quality includes delivery performance, responsiveness to the change of the environment and market, the lowest possible cost in service. Deming (1982) also identifies three types of qualities which are essential for producing goods and services that meet the needs of customers 
and clients, such as quality of design or re-design, quality of conformity and quality of performance. Garvin (1988), discusses the evolution of the concept of quality, identifies five perspectives such as the transcendent quality - view; product based approach; user based approach; manufacturing based approach and the definition of the value based on quality. The role of the public sector in the delivery of quality services is far more important in the developing countries.

According to Gowan et al. (2001), providing service in public sector are more complex because it is not only a matter of meeting the stated needs but also finding out the stated needs, setting the priorities, and allocating public resources.Public sector organisations are always under pressure to provide quality services (Randall \& Senior, 1994) and improve efficiency (Robinson etal., 2005).

Quality of service has been identified and documented as one of the major driving forces for organizational survival, sustainability, and it is crucial for the achievement of the company (Rust\& Oliver, 1994). Quality of service has been defined and conceptualised differently by different experts, researchers and practitioners. According to Zeithaml and Bitner (2009:85), "Focusedservice quality evolution reflects customer" a certain perception of service quality dimensions includes reliability, responsiveness, assurance, empathy, and tangibility."It means that a conceptual construction that is centered on the perception of quality which is defined as customer's 'assessment of the entity'to overall excellence or superiority (Zeithaml, 1987).

According to Parasuraman et al. (1985), quality of service is the difference between the expected and the perceived service by the customer. If the expectation is greater than the performance of the service, then the perception of service quality is less satisfactory and it is dissatisfaction.

Service quality, according to Tjiptono (2012: 121), is “a measurement of how a service meets the consumer's expectation". In line with the definition, quality can be achieved through gratification of needs and demands of customers and accuracy in delivering the message to meet the customers' expectations. Therefore, there are two main factors influencing the quality of service: expected service and perceived service. If the perceived service is equal to the expected service, the quality, then, is perceived well or positively. If the perceived service is more than the expected service, the quality of the service is perceived as ideal quality. On the other hand, if perceived service is poorer than the expected service, then the service quality is perceived as bad or poor.

\subsection{People and Consumers' Satisfaction Index}

People's Satisfaction Index is data and information of people satisfaction level acquired from quantitative and qualitative measurement result on people's opinion about the service of public service administrator apparatus by comparing the expectations and the needs. The index elements of public service user satisfaction in reference to Apparatus Empowerment Ministry NUMBER: KEP/25/M.PAN/2/2004 about General Guidelines of People's Satisfaction Index Organisation in Government Instance Service Unit are as follow:

1) Service is simplicity on service stages delivered to people;

2) Service requirements that cover technical and administrative requirements needed to get the service according to its service type;

3) Service Certainty that includes the clear existence and certainty of the officers who are in charge (name, authority and responsibility position);

4) Service discipline of the officers, includes seriousness of the service officers in delivering the service especially their commitment on their effective working based on the regulation;

5) The responsibility of the service officers covers authority and responsibility certainty of the officers in administering and delivering services;

6) The capability of the service officers is the officers' competence and skill in delivering and administering service to people;

7) Speed of service, means that the target of service time can be done within the time set by the units of service providers;

8) Fair in the service, it allows the implementation of service which does not distinguish the class or status of the communities;

9) Courtesy and hospitality of the officer: the attitude and behavior of officers in providing services to the community are polite and friendly as well as to promote mutual respect and honour;

10) Even service charge provides the affordability of the public against the fees imposed by service units for a certain service; 
11) Fixed service charge bridges the fees paid by the community with the charges of service;

12) Regular schedule of service allows implementation of the service time in line with the conditions that has been set;

13) Comfortable surroundings produce clean, neat, and organized condition of facilities and infrastructure, so it provides coziness to the customers;

14) Security in services ensures the environmental level of security at the units or service providers: therefore the people feel calm and relaxed to get the service from certain risks as a result of the implementation of the service.

\subsection{Services at Public Sector}

According to the Act No. 25, 2009 the public service is an activity or series of activities, which is conducted to meet a service needs; it is administrated by the laws for every citizen and resident for the goods, services, and or administrative services provided by public service providers.

Rudianto (2005) stated that the core of public service is the attitude of being helpful, friendly and professional in providing services or products from a certain agency that satisfy the society. Public service demands of each element in the agency to empathise with the public. It implies a certain meaning; as the ability of government bureaucrats to put themself on the community and comprehend the things or issues from a community perspective.

Suparto (2008:15), also said "public service is the provision of the services performed by the government as state officials to meet the needs of the community (the public) in accordance with relevant regulations".

Some definition of Public Sector Services according to Ministry Decree PAN No. 25/M.PAN/2/2004:

1) Public Service Unit is working unit or serving office on government agencies, which is directly or indirectly giving services to the customers.

2) Staff of Public Services is government official who has a duty and function of public services in line with the government regulation.

3) The recipient of public services is a person, the community, institution of government, and business sector, who receive services from the officers of public services.

4) The cost of public services is all the costs (with any name) as compensation for the provision of public services; the amount and payment procedures are established by the competent authorities in line with laws and regulations.

The essential requirement to create better public services according to Act No. 25, 2009 are:

1) Leader Commitment

Technical efforts that can be done by the officers always require the support of decision-makers (the leaders) both in the local and in the central government. It means that the commitment is intended to be a strong and consistent desire to make continuous improvements. This commitment was followed by a policy, a similar decision in relation to the allocation and utilization of resources in order to improve the quality of public services.

2) Changes in the mindset of the service function

Change of mindset is the beginning of all efforts at improvement and has a very big influence to the overall process of improving public services. If there is no new comprehension of the importance and benefits of improving public services for individual and organisational apparatus, the real action in that direction will never come true.

3) Public participation as a service users

Improving the quality of public services is difficult to be achieved when the participation of user is still low. The most important aspects of service user participation is their aspiration for variety, quality and cost of service delivery. Otherwise, it is very likely that the organisers and executors of public service will organise and implement services that actually produce something that is not needed or not desired by the users of the service. 
4) Trust

The key to success for improving public services is mutual trust between the person in charge, organizers and officers of public service with their community of user. Mutual trust will generate positive communication and interaction and create more meaningful service in the administration and implementation process.

5) Awareness of organizers and officers at public service

Awareness is always associated with the level of responsiveness and accountability to the implementation of public services. Many cases demonstrate organizational inertia of organisers and officers as public service providers to find the entry to the improvement of service quality due to lack of awareness of the organisation on the quality of public services management. Insensitivity of the problem will lead to a dull of sensitivity to the aspirations of service users as well as the loss of a willingness to make significant progress. The personnel in the organization of service providers and decision-makers need to be convinced that the repair of the service is an obligation. If there is no awareness, an initial process should be taken into account although it will take some time.

\section{6) Openness}

The main obstacle encountered in the effort to improve the quality of service is transparency which is not owned by either the service provider or the service recipient. Transparency means the willingness to accept complaints or criticisms and at the same time to take real action to improve those things. Openness can also be interpreted as a willingness to communicate with others effectively. The most important aspect of transparency is to be honest with the real condition.

\section{7) The Availability of Budget}

The availability of the budget is regarded as a key strategy to be succeesful in improving the quality of the public services. The improvement budget of public services should be an integral part of the overall budget from a certain working unit that has a responsibility in that area. In other words, the continuous improvement of service quality is an inherent part of the overall duty of the organization and implementation of public service.

\section{8) The Growing Sense of Belonging}

On the side of the community as service users, it should be developed confidence that their contributions are needed and their aspirations will be considered. It is useful to motivate engagement sense. We must believe that the solely purpose (motivation) to submit a complaint is for the sake of a service improvement, and there is no other motives.

\section{9) Surveys and any Participation of Service Users Must be Followed by Real Action of Improvement}

Complaint surveys may be hard psychologically for the organizers of public service, but when organised professionally, it is a good starting point to show positive change and to gain trust. Therefore, service providers should participate actively and take primary responsibility in the whole process of implementation. The purpose of survey is just a tool to determine the initial status of the performance and quality of service. If the initial status is not followed by real improvement and carry out the survey again, sooner or later apathy will appear among the implementers especially the service users.

\section{0) Honesty}

Honesty is an important factor in improving the quality of public services. Honesty towards the problems will guide into the right solution. Meanwhile, an attempt to cover up the real problem which exists through defensive mechanisms will deceive all parties away from the solution and appropriate remedial action.

\section{1) Realistic and fast}

Real improvement efforts should be made in order to give the real impression, which is fast, easily percieved, the changes are observable and beneficial to the user of community services. It has to be believed that people always have sufficient awareness and tolerance to the limit ability of the organisers and executors of public services that they may not resolve the entire issue at once. The real action, though simple, is much better assessed and more valuable than a great action but it is still hold out the new promise and it can not necessarily be realised.

\section{2) Feedback and public relations}

It is an obligation to give feedback as soon as possible on each case which has received and requested from the public. If people were asked (as respondents) to give an opinion (vote), do not put off too long to notify them the result of the survey as a feedback. That is why in some cases, scientific surveys with the scientific method often gives a results that are not too easy to be processed and as a feedback cannot be understood by the respondents. 
13) Increasing the courage and habit of receiving the complaint

Generally, no one was happy with the complaint against him/herself. Everyone has to start to learn to understand that criticism, complaints (in general) is more honest than praise or flattery. This is because praise is given for the benefit of someone else. If not, then it is definitely a compliment which contains dishonesty. Instead it is almost certain that if someone comes to criticism, complaint or protest, it is done for self-interest. Everyone is generally more honest in the interests of his own. That is why the complaint and criticism, though noticeably bitter, are generally more honest and more factual than praise or flattery that is sweet.

14) Experience success in using methods

Though small, initial successes will always be more motivating than a failure. In that case, doing the little things, simple but produces real change, becomes very important to cultivate the courage to do things bigger and more complex. It is better not to start complicated things with the unpredictable risk of failure, because failure tends to lead to demotivation.

\subsection{Standard of Public Sector Services}

According to the Decree of the Minister of State for Administrative Reform Number: 63 / KEP / M.PAN / $7 / 2003$ that every public service should have a standard of service and be published as a guarantee of certainty for service users. The standard of service is a measure that is standardised in public service that must be obeyed by the party who delivers and uses the service. Minimum service standards cover:

1. Procedure of service

Standardised procedures for service providers and recipients of services including complaints.

\section{Solution time}

The time which is allocated from the time of submission of the applicant until the completion of the service, including complaints.

\section{Cost of services}

Costs or tariffs which include the detail that has been set in the service.

\section{Products of services}

The results of the services which will be received in line with the regulation conditions.

\section{Facilities and infrastructure}

The provision of facilities and infrastructure which is adequate by the public service providers.

\section{Competence of personnel service providers}

Competence of personnel service providers should be set appropriately based on requirement of knowledge, expertise, skills, attitudes and behaviors.

\subsection{Performance of Public Sector Organizations}

Performance as a term, means the final result of an activity in carrying out job responsibilities as efficiently and effectively as possible. Managers need to understand that the concept of "Organizational Performance " is the final result of the accumulation of all the working processof the organization and he/she needs to understand the factors that lead to high performance on the organization (Robbins and Coulter , 2005: 465).

Low, David and Others (2008) has conducted a research which measures the performance and the responsibility of public sector organizations to the public. The final objective of performance measurement in the public sector is to improve the control of government expenditure, both from inside and outside the government, and to ensure confidence in the public that public organizations that receive public funds must achieve and demonstrate high performance efficiently and effectively.

\section{Research Methods}

This research was conducted in Malang Immigration Office Class 1, which runs the public service functions of the Directorate General of Immigration in the city of Malang. The population in this study are all the applicants for a passport at the Immigration Office Class 1 Malang, Indonesia. In this study, the sample is taken by using purposive sampling technique and the respondents are the applicants who use the administrative service of applying a passport process from the start until finish. Service to customer in the public organisation sector can be measured by asking questions on the hospitality of officers, good manners, the clarity of requested information, the needs analysis, and timeline of service. All of these questions are to test the ability of public 
sector organizations in addressing some of the categories of customer, another survey should be conducted to measure the usefulness of available information and services, and it consists of several questions such as relevance, accuracy, timeliness, scope, and ease of access ( Kirkendall , 2008) .Type of random question which is used to collect answers could determine defect in public organizations that cause resistance to performance and create a deficiency in customer perception. (Wood and others, 2007)

According to Act No. KEP/25/M.PAN/2/2004 in determining the number of samples, the respondents are selected randomly which are determined according to the coverage area of each service unit. To meet the accuracy of the results of the index preparation, 150 respondents was selected out of a population of service recipients as a minimum set, with the base ("Number of elements" +1$)$ x $10=$ number of respondents $(14+1) \times$ $10=150$ respondents. The technique of data collection, the researcher distributes a questionnaire to the respondents and the respondents will answer to each question with an answer scale: $\mathrm{A}=$ weight value of $1 ; \mathrm{b}=$ weight value of $2 ; \mathrm{c}=$ weight value of $3 ; \mathrm{d}=$ weight value of 4 .

\section{Data Analysis Technique}

The researcher uses data analysis technique in this research by applying Public Satisfaction Index, which is measured by using weighed score from each of service elements. In measuring Public Satisfaction Index, there are 14 elements or indicators which are under inspection. Every elements of service has the same weigh which is formulated as follows:

$$
\text { Score Quality of weighed estimation }=\frac{\text { sum of weight }}{\text { sum of elements }}=\frac{1}{14}=0,071
$$

The formula to get the score of Public Satisfaction Index is:

$$
\text { Satisfaction Index }=\frac{\text { sum of perception score each elements }}{\text { sum of filled elements }} \times \text { weighted score }
$$

To simplify the interpretation of measuring Public Satisfaction Index which is around $25-100$, the result of measurement above is converted with basic score 25, by using the following formula: Public Satisfaction Index of Service unit x 25.Thus the results can be seen in Table 1 .

Table 1. Perception Value, Interval of Public Satisfaction Index, Interval Score of Conversion Public Satisfaction Index, Quality of Service, and Performance of Unit Services

\begin{tabular}{lllll}
\hline $\begin{array}{l}\text { Perception } \\
\text { Value }\end{array}$ & $\begin{array}{l}\text { Interval of Public } \\
\text { Satisfaction Index }\end{array}$ & $\begin{array}{l}\text { Interval Score of Conversion Public } \\
\text { Satisfaction Index }\end{array}$ & Quality of Service & $\begin{array}{l}\text { Performance of Unit } \\
\text { Services }\end{array}$ \\
\hline 1 & $1,00-1,75$ & $25,00-43,75$ & D & Poor \\
2 & $1,76-2,50$ & $43,76-62,50$ & C & Not good \\
3 & $2,51-3,25$ & $62,51-81,25$ & B & Good \\
4 & $3,26-4,00$ & $81,26-100,00$ & A & Excellence \\
\hline
\end{tabular}

\section{Data Analysis}

\subsection{Profile of Respondents}

Sampling technique in this study is purposive sampling, therefore the researcher has selected 150 people who are an active users of the service; the 150 sample has different backgrounds, in terms of age, place of birth, level of education, gender, and occupation. The division and percentage of age respondents are between 21-30 years old as many as 50 people or $33.33 \%$ and this is the largest group, while the least are $\leq 20$ years old there are 8 people, or $5.33 \%$, then $41-50$ years old, there are 28 people or $18.67 \%$, then $\geq 51$ years old there are 31 people of $20.67 \%$, and $31-40$ years old or around to 33 people or $22 \%$. Data by gender showed that the type sex of the entire user community services respondents, male respondents are 84 people or $56 \%$, while women are 66 people or $44 \%$. It is clear that the number of male respondents is higher than that of females in this study. Distribution of education levels indicates that the distribution of educational level of respondents who dominate the service user community is S1 (undergraduate) level for about 73 people or $48.67 \%$ and the smallest number is on elementary education for 1 person or $0.67 \%$. Distribution of respondents' job indicated that the main job distribution of service users is dominated by respondents who has another job, for about 45 people or $30 \%$. What is meant by another job is out of four categories which have been listed by the writer in the questionnaire; for example housewives, retired employees, people with mixed jobs, and migrant labor applicant. While the least are those who work as entrepreneurs, around 18 people or $12 \%$. 


\subsection{The Results of Each Element of Public Satisfaction Index}

The study results of Public Satisfaction Index on service quality based on an existing element in the Administrative Reform Decree Ministry No. 25 / M.PAN / 2/2004, February 24, 2004 on General Guidelines for Public Satisfaction Index Preparation in Government Instances Services Unitof Government Agencies, which has 14 indicators. Each indicator will be conducted the data tabulation to obtain the frequency and percentage of each unit of service, the description of each unit is:

1) Service is simplicity on service stages delivered to people; the results of tabulation of the data respondent about the service procedure showed there are 3 people or $2 \%$ of respondents gave the answer that the procedure is not easy, 9 people or $6 \%$ of respondents said less easy, 122 people or $81.33 \%$ said easy and the remaining 16 people, or $10.67 \%$ said it was very easy.

2) Service requirements that cover technical and administrative requirements needed to get the service according to its service type; for service requirements elements which are described in Table 4.6, 2 people, or 1.33\% of the respondents stated it is not appropriate, 9 people or $6 \%$ of respondents said less appropriate, 131 people or $87.33 \%$ of respondents stated it is appropriate, while the remaining 8 or $5.33 \%$ of respondents said it was very appropriate.

3) Service Certainty that includes the clear existence and certainty of the officers who are in charge (name, authority and responsibility position); Based on Table 4.7 on the clarity element of service officers, it can be explained that there is 1 person or $0.67 \%$ of respondents say that it is not clear, 14 people or $9.33 \%$ it is less clearly stated, 125 people or $83.33 \%$ it is stated clearly, and the remaining 10 people or $6.67 \%$ it is stated very clearly.

4) Service discipline of the officers, includes seriousness of the service officers in delivering the service especially their commitment on their effective working based on the regulation; according to the table 4.8, it is obvious that there are 2 people or $1.33 \%$ of respondents said the officers are not discipline, 36 people or $24 \%$ of respondents said the officers are lack of discipline, 94 people or $62.67 \%$ stated that the officers are discipline, and the remaining 18 people or $12 \%$ of respondents stated, the officers are very disciplined.

5) The responsibility of the service officers covers authority and responsibility certainty of the officers in administering and delivering services; the survey shows that there are 21 people or $14 \%$ of respondents stated that the officers lessresponsible, 123 people or $82 \%$ of respondents claimed that the officers are well responsible and the remaining 6 people or $4 \%$ of respondents stated that the officers are very responsible.

6) The capability of the service officers is the officers' competence and skill in delivering and administering service to people; the results of survey showed that 5 people or $3.33 \%$ of respondents said that the officers are less capable of serving the community, 135 people or $90 \%$ of respondents said that they are capable and 10 people or $6.67 \%$ of respondents stated the officers are very capable.

7) Speed of service, means that the target of service time can be done within the time set by the units of service providers; from the results of the data tabulation, there are 8 people or $5.33 \%$ of the respondents stated that the process of applying passport service in Malang Immigration Office Class 1 are not fast, 31 people or $20.67 \%$ of respondents said it is less fast, 110 people or $73.33 \%$ respondents said it is fast and 1 or $0.67 \%$ of respondents stated that it is very fast.

8) Fair in the service, it allows the implementation of service which does not distinguish the class or status of the communities. From the results of the data tabulation of the respondent showed there are 4 people or $2.67 \%$ of the respondents stated that the passport application service in Malang Immigration Office Class 1 were not fair, 22 people or $12.67 \%$ of respondents said it was less fair, 116 people or $77.33 \%$ respondents said it was fair, and the remaining 8 people or $5.33 \%$ of respondents stated it was very fair.

9) Courtesy and hospitality of officer: the attitude and behavior of officers in providing services to the community are polite and friendly as well as to promote mutual respect and honour; from the results of the data tabulation of the respondent showed there are 7 people or $4.67 \%$ of respondents stated that officers are less polite and friendly, 130 people or $86.67 \%$ of respondents stated that the officers are polite and friendly, and 13 people or $8.67 \%$ of respondents stated that the officers are very polite and friendly.

10) Even Service Charge provides the affordability of the public against the fees imposed by service units for a certain service; the results of the data tabulation of the respondent, there is 1 person or $0.67 \%$ of the respondents states that the cost of a passport at the Immigration Office Class 1 Malang is not reasonable, 7 people or $4.67 \%$ of respondents say that it is less fair, 135 people or $90 \%$ of respondents it is reasonable, and 7 people or $4.67 \%$ of respondents stated very reasonable. 
11) Fixed Service Charge bridges the fees paid by the community with the charges of service; from the results of the data tabulation of the respondent shows there are 2 people or $1.33 \%$ of the respondents stated that the fees paid are not always appropriate to the normal charge, 26 people or $17.33 \%$ of respondents say it is sometimes appropriate, 55 or $36.67 \%$ of respondents state that it is very appropriate, and 68 people, or $45.33 \%$ of respondents state that it is always appropriate.

12) Regular schedule of service allows implementation of the service time in line with the conditions that has been set; from the results of the data tabulation of the respondent show that there are 2 people or $1.33 \%$ of the respondents stated that the implementation of the service time is not always appropriate to the condition that has been set, 32 people or $21.33 \%$ of respondents say it is sometimes appropriate, 73 people or $48.67 \%$ of the respondents state that it is very appropriate, and the remaining 43 people, or $28.67 \%$ of respondents state that it is always appropriate.

13) Comfortable surroundings produces clean, neat, and organized condition of facilities and infrastructure, so it provides coziness to the customers; from the result of the data tabulation of the respondent, there is 1 person or $0.67 \%$ of respondents said that the environment of the service is uncomfortable, 4 people or $2.67 \%$ of respondents say that it is less comfortable, 134 people or $89.33 \%$ of respondents state that it is comfortable, and 11 people or $7.33 \%$ of respondents state that it is very comfortable.

14) Security in Services ensures the environmental level of security at the units or service providers: therefore the people feel calm and relaxed to get the service from certain risks as a result of the implementation of the service; from the results of the data tabulation of the respondent in Table $4: 18$, there are 3 people or $2 \%$ of respondents say it is less safe, 138 people or $92 \%$ of respondents declare it is safe, and the remaining 9 people or $6 \%$ of respondents state that it is very safe.

\subsection{Data Analysis on Satisfaction Index of Public Service User}

Elements of the public service user satisfaction index according to Minister of State for Administrative Reform KEP / 25 / M.PAN / 2/2004 on General Guidelines for Public Satisfaction Index Preparation in Government Instances Services Unit. are as follows: service procedures, service requirement, service certainty, service discipline of the officers, the responsibility of the service officers, the capability of the service officers, speed of service, fair in the services, courtesy and hospitality of the officer, even service charge, fixed service charge, regular schedule of service, comfortable surroundings, and security in services.

Stages in analyzing satisfaction index of public services users are as follows:

\section{1) Calculating the Amount of Each Element Service.}

The answer of each respondent from each element are summed, the result is as shown in Table 2. For every answer A, the value then is multiplied by 1 , answer B is multiplied by 2 , answer C is multiplied by 3 , and 4 for the answer D. Thus the results can be seen in Table 2.

Table 2. Total Score per Element

\begin{tabular}{ll}
\hline Elements of Service & Total Score per Elements \\
\hline service procedures & 451 \\
service requirement & 445 \\
service certainty & 444 \\
service discipline of the officers & 428 \\
the responsibility of the service officers & 435 \\
the capability of the service officers & 455 \\
speed of service & 404 \\
fair in the services & 428 \\
courtesy and hospitality of the officer & 456 \\
even service charge & 448 \\
fixed service charge & 488 \\
regular schedule of service & 457 \\
comfortable surroundings, & 455 \\
security in services & 456 \\
\hline
\end{tabular}


2) Calculating the Average Score of Each Service Element

$$
\text { Average Score of Each Element }=\frac{\text { TotalScoreperElement }}{\text { TotalQuestionnaire }}
$$

Table 3 describes the average score per service elements.

Table 3. Average Score per Service Elements

\begin{tabular}{ll}
\hline Elements of Service & Total Score per Elements \\
\hline service procedures & 3,01 \\
service requirement & 2,97 \\
service certainty & 2,96 \\
service discipline of the officers & 2,85 \\
the responsibility of the service officers & 2,90 \\
the capability of the service officers & 3,03 \\
speed of service & 2,69 \\
fair in the services & 2,85 \\
courtesy and hospitality of the officer & 3,04 \\
even service charge & 2,99 \\
fixed service charge & 3,25 \\
regular schedule of service & 3,05 \\
comfortable surroundings, & 3,03 \\
security in services & 3,04 \\
\hline
\end{tabular}

3) Calculating the Average Weighted Score of Each Service Elements

Average Weighted Score per elements = Average Weighed Score per elements X 0,071

Weighted Average Value per Element can be seen in Table 4.

Table 4. Average Weighted Score per Elements

\begin{tabular}{ll}
\hline Elements of Service & Weighted Average Value per Element \\
\hline service procedures & 0,213 \\
service requirement & 0,211 \\
service certainty & 0,210 \\
service discipline of the officers & 0,203 \\
the responsibility of the service officers & 0,206 \\
the capability of the service officers & 0,215 \\
speed of service & 0,191 \\
fair in the services & 0,203 \\
courtesy and hospitality of the officer & 0,216 \\
even service charge & 0,212 \\
fixed service charge & 0,231 \\
regular schedule of service & 0,216 \\
comfortable surroundings, & 0,215 \\
security in services & 0,216 \\
\hline
\end{tabular}

4) Calculating the Score Public Satisfaction Index.

To facilitate the interpretation of the Public Satisfaction Index assessment, which is between 25-100; then result of this research is converted by using 25 as a basic score, by applying the following formula:

Public Satisfaction Index after the score is converted $=$ Score $x$ Score Index Base $=2,958$ x $25=73.958$. Based on the above calculation, the score which is obtained for SMEs after conversion is 73.958 , so the quality of services in Class 1 Malang immigration office is B, which means good service performance.

\section{Discussion and Conclusion}

From the analysis of data that describe the quality of service that includes service procedures, service requirement, service certainty, service discipline of the officers, the responsibility of the service officers, the capability of the service officers, speed of service, fair in the services, courtesy and hospitality of the officer, 
even service charge, fixed service charge, regular schedule of service, comfortable surroundings, security in services of the amount score per elements and the average score per elements shows that the highest score is the even service charge means that the consumer/public needs transparency to the cost of service of government services. Service of public sector customer consists of all actions which is conducted by the organization to obtain customer satisfaction and help to acquire the most value products and services that have been purchased. Customer satisfaction is the source of organizational benefit (Rosta et al., 1988). Quality of service regards as a trade - off between value and price. By comparing account the trade-off between performance (or conformity) and the price, quality is defined as "affordable excellence". (Lovelock \&Wirtz, 2004).

The researcher also finds that the lowest element of service is speed of service. Hamali and Zamhari (2014) explains that the officer must have excellent interpersonal skills, it is significant for public institutions to have employees who can inspire confidence among consumers. Officers must be knowledgeable in answering every customer inquiries, and illustrate respectable behavior that can raise customer confidence. Abdullah, \&Zamhari (2013) explains that there are five critical success factors of the quality of public sector services which must be developed to provide the best service such as systematization, efficiency, security, hospitality and attention of employees. Birori(2014) explains that the aim of employees training in public sector organizations in providing customer services is to improve interaction, respect, courtesy and behavior, beside it should also increase the dimension of assurance through the expand of employees knowledge in responding and answering complaints of client. To build trust, training program should improve the expertise and train employees in different areas to solve several peoblems such as the resolution of client issues, the provision of services within the schedule, and the accuracy and speed of the job.

Agus (2007) explains that the results of research on public sector services will serve as the government guidelines for further improvement and adjustment in providing superior quality services to customers. Excellent quality of service is very important for public agencies even though it is non-profit.Hildreth (1999) explains that more transactions will be done between the customer and the service provider when citizens (customer) are satisfied. A number of authors have different thoughts on defining customer in the public service.

Based on variable calculation of Customer Satisfaction Index which is contained in the Decree of the Minister of State for Administrative Reform Number: KEP/25/M.PAN/2/2004 on General Guidelines of People's Satisfaction Index Organisation in Government Instance Service Unit, the assessment result of passport services at the Immigration Office 1 Malang in the category of service quality is B. Performance of Immigration Office Class 1 Malang in accordance with the performance standards which has been set by the government is good. Rowley, J. (1998) explains that the success and performance of public sector organizations by using the dimensional evaluation services helps the organisations in developing strategies to achieve competitive advantage significantly.

\section{Limitations of the Study}

The limitations of this study lies within the cross-check between the primary and secondary data, it can not be done well because of bureaucratic problem of theImmigration office.

Research Implications.

\section{1) Malang Immigration Office Class I}

This study is useful for the Malang Immigration Office Class I, it can be used as a valuable consideration of administrative service improvement programs, particularly in fixing the long queue by adding more officers and equipment.

\section{2) Consumer or Public}

This study is useful for the public as the consumer as a reference for the rights that should be available as a citizen to obtain services of public sector administrative unit of government; as it is constituted in UUD 1945.

\section{References}

Abdullah, F.,\& Zamhari, U.A. (2013). Managing Critical Factors Affecting Service Quality for the Public Sector. Proceedings of 23rd International Business Research Conference, Melbourne, 18-20 November 2013.

Agus, A. (2007). An empirical test of TQM in public service sector and its impact on customer satisfaction.Journal of Quality Measurement and Analysis, 131-137.

Anderson, E. (1995). Measuring Service Quality in a University Health Clinic. International Journal of Health Care Quality Assurance, 8(2), 32-37.http://dx.doi.org/10.1108/09526869510081866 
Arawati, S. B.,\& Kandampully, J.(2007). An exploratory study of service quality in the Malaysian public service sector.International Journal of Quality and Reliability Management, 24(2),177-190.

Babakus, E.,\& Boller, G. W. (1992). An Empirical Assessment of the SERQUAL Scale.Journal of Business Research, 24(3), 253-268.

Birori,O. W. (2014). Internal Customer Satisfaction Assessment In The Public Sector: A Case Study Of Fleet Management Services Delivery. International Journal of Recent Research in Commerce Economics and Management, 1(2), 12-28.

Cohen, S.,\& Brand, R. (1993).Total Quality Management in Government: A Practical Guide for the Real World. San Francisco, CA: Jossey-Bass.

Deming, W. E. (1982).Out of the Crisis.Cambridge, Mass: Massa Chusetts Institute for Technology.

Dwiyanto, A. (2003). Reformasi Tata pemerintahan dan Otonomi Daerah. Pusat studi Kepedudukan dan Kebijakan Universitas Gajah Mada, Yogyakarta.

Dwiyanto, A., Partini, R., Wicaksono, B., Tamtiari, W., Kusumasari, B., \& Nuh, M. (2002).Reformasi Birokrasi Publik di Indonesia. diterbitkan Pusat Studi Kependudukan dan Kebijakan UGM, Galang Printika, Yogyakarta.

Garvin, D. A. (1987). Competing on the Eight Dimensions of Quality.Harvard Business Review, 65(6), 101-109.

Garvin, D.A. (1988). Managing Quality: The Strategic and Competitive Edge.In D. H. Besterfield et al. (Eds.),Total Quality Management.

Glaser, M.A.,\& Hildreth, W.B. (1999).Service delivery satisfaction and willingness to pay taxes: citizen recognition of local government performance.Public Productivity \& Management Review, 23, 48-67.http://dx.doi.org/10.2307/3380792

Gowan, M., Seymour, J., Ibarreche, S.,\& Lackey, C. (2001). Service quality in public agency: same expectations but different perceptions by employees, managers and customers.Journal of Quality Management, 6, 275-291.http://dx.doi.org/10.1016/S1084-8568(01)00040-2

Groonroos, C. (1990).Service Management and Marketing Service Sector. Cambridge, MA: Marketing Science Institute.

Hamali, A. (2014). Public Sector Service Quality: The Critical Success Factors 2.

Hsiao, C. T.,\& Lin, J. S. (2008). A Study of Service Quality In Public Sector. InternationalJournal of Electronic Business Management, 6(1),29-38.

Ilhaamie. (2008).Service Quality in Malaysian Public Organizations.International Journal of Knowledge, Culture and Change, 8(5), 129-138.

Improvement and Development Agency for Local Government. (2005).A beginners Guide to Customer Satisfaction. United Kingdom.

Jamil, H., \&Firdaus, Z. (2014). Public Sector Service Quality: The Critical Success Factors.

Katsutushi, A. (2005). Introduction on total quality management. Translated by Yousefi R. 13-55.

Khalid, S., Mahmood, B., \&Abbas, M. (2011). Customer Satisfaction with Service Quality in Conventional Banking in Pakistan: The Case of Faisalabad.International Journal of Marketing Studies, 3(4).

Kirkendall, N. J. (2008). Organizational Performance Measurement in the Energy Information Administration.U.S.A.

Lovelock, C.,\& Wirtz, J. (2004).Service Marketing: People, Technology, Strategy (5th ed.).

Low, D. et al. (2008).Performance Measurement. Canada.

Mote, F. (2008).Analisis Indeks Kepuasan Masyarakat Pelayanan Publik Di Puskesmas Ngesrep Semarang.

Ningsih, F. (2013). Kinerja Aparat Pemerintah Dalam Pelayanan Publik Di Kantor Desa Entikong Kecamatan Entikong Kabupaten Sanggau. Pakistan.Journal of Library \& Information Science.

Nor, M.N., Khalid, S. A., Razali, M.F.M., \& Ramli, N.A. (2010).Service Quality and Customer Satisfaction: The Public Sector Perspective.

Osborn, D.,\& Gabler, T.(1995).Reinventing Government: How the Entrepreneurial Spirit is transforming the Publik Sector. 
Phillips, L. W., Chang, D. R.,\& Buzzell, R. D. (1983). Product Quality, Cost Position and Business Performance: A Test of Some Key Hypothesis.Journal of Marketing, 47(spring), 26-43.http://dx.doi.org/10.2307/1251491

Randall, L.,\& Senior, M. (1994). A model for achieving quality in hospital hotel services.International Journal of Contemporary Hospital Management, 6,68-74.http://dx.doi.org/10.1108/09596119410052161

Robbins, S., \& Coulter, M. (2005).Management. New Jersey: Prentice Hall.

Rosta, A., Venus, D.,\&Ebrahimi, A. (1997). Marketing management.

Rowley, J. (1998). Quality measurement in the public sector: some perspectives from the service quality literature.Total Quality Management, 9, 321- 333.http://dx.doi.org/10.1080/0954412989171

Rudianto, Y. (2005). Pelayanan Publik Pada Penyelenggaraan Pemerintah Kecamatan. Jurnal Madani Edisi II.

Rust, R.T.,\& Oliver, R.L. (1994).Service Quality: Insights and Managerial implications from the frontier.In R. T.Rust \& R.L.Oliver (Eds), Service Quality: New Directions in Theory and Practice(pp. 1-19). Sage Publications, Thousand Oaks, CA.http://dx.doi.org/10.4135/9781452229102.n1

Saghier, N. E., \&Nathan, D. (2013). Service Quality Dimensions and Customers' Satisfactions of Banks in Egypt.Proceedings of 20th International Business Research Conference 4 - 5 April 2013, Dubai, UAE, ISBN: 978-1-922069-22-1

Sancoko, B. (2010). Pengaruh Renumerasi terhadap Kualitas Pelayanan Publik.Jurnal Ilmu Administrasi dan Organisasi.

Setyaningsih, N. (2008). Analisis Indeks Kepuasan Masyarakat Di Samsat Kabupaten Sragen.

Suparto, P. (2008). Paradigma \& Implementasi Pelayanan Publik.Malang: Kanisius.

Suprapto, J., \&Limakrisna, N. (2011). Pemasaran untuk Pimpinan Sekor Publik dan Organisasi Nirlaba yang Visioner. Jakarta:Salemba Empat.

Teicher, J., Hughes, O., \& Dow, N. (2002). E-government: a new route to public service quality.Managing Service Quality, 70, 423-433.

Thoha, M. (2004). Administrasi Negara dan Kualitas Pelayanan Publik, dalam Dialogue.Jurnal Ilmu Administrasi dan Kebijakan Publik.MAPUNDIP, Semarang.

Undang-undang No 25 Tahun 2009 tentang Pedoman Peningkatan Kualitas Pelayanan Publik dengan Partisipasi Masyarakat.

Undang-undang Nomor: 63/KEP/M.PAN/7/2003 tentang Pedoman Umum Penyelenggaraan Pelayanan Publik.

Undang-undang Nomor: KEP/25/M.PAN/2/2004 tentang Pedoman Umum Penyusunan Indeks Kepuasan Masyarakat Unit Pelayanan Instansi Pemerintah.

Ur Rehman, S. (2012).Measuring service quality in public and private sector. university libraries of Pakistan.

Wood, S., Webb, P., \& Page, S. (2007).Measurement of Customer Satisfactionand Performance Measurement within a local Government Framework, England.University of Chester.

Zamil, S. (2011). Role of Measuring Customer Satisfaction in Improving the Performance in the Public Sector Organization.Journal of Business Studies Quarterly, 2(3), 32-41.

Zeithaml, V. A. (1987).Defining and Relating Prices,Perceived Quality and Perceived Value.Marketing Science Institute, Cambridge, M.A.

Zeithaml, V. A., \&dan Gremler, B. (2009). Service Marketing - Integrating Customer Focus across the Firm. New York: Mc. Graw Hill.

Zeithaml, V. A., Parasuraman, A.,\& Berry, L.L. (1985). A conceptual Model of Service Quality and its implications for Future Research. Journal of Marketing, 49,41-50.

Zeithaml, V. A., Parasuraman, A.,\& Berry, L.L. (1988). SERVQUAL: A Multiple Item Scale for Measuring Customer Perceptions of Service Quality.Journal of Retailing, 64, 12-40.

Zeithaml, V. A.,Parasuraman, A.,\& Berry, L.L. (1990).Delivering Quality Service: Balancing Customer Perceptions and Expectations. New York., NY: The Free Press. 


\section{Copyrights}

Copyright for this article is retained by the author(s), with first publication rights granted to the journal.

This is an open-access article distributed under the terms and conditions of the Creative Commons Attribution license (http://creativecommons.org/licenses/by/3.0/). 